\title{
Extinction Risk Assessments at the Species Level: National Red List Status of Endemic Wild Cinnamon Species in Sri Lanka
}

\author{
D.M.H.C. Kumarathilake, S.G.J.N. Senanayake ${ }^{1}$, G.A.W. Wijesekara ${ }^{2}$ \\ D.S.A. Wijesundera ${ }^{3}$ and R.A.A.K. Ranawaka ${ }^{4}$
}

Department of Agricultural Biology

Faculty of Agriculture, University of Ruhuna

Sri Lanka

\begin{abstract}
Cinnamomum is one of the most important genera among the crop wild relatives in Sri Lanka. Out of the eight Cinnamomum species that grow in Sri Lanka, Cinnamomum verum is indigenous, Cinnamomum camphora is introduced while the other remaining Cinnamomum species are endemic to Sri Lanka. The main objectives of this study were to determine the national red list status of the endemic wild cinnamon species and to assess the extinction risk of them. Only the seven endemic wild cinnamon species were included in the study. The study was mainly based on the eco-geographical survey which consisted of the study of the herbarium specimens to collect reliable secondary data and development of potential distribution maps using available data. DIVA-GIS software was used to develop potential maps. Thereafter, high potential areas were identified using the above maps and field visits were made to collect primary data. Collected primary data were analyzed and national red listing criteria were applied. According to the ecogeographical survey, Cinnamomum dubium found in wet zone forests was the most common species. Average red listing scoring value (ARLSV) of Cinnamomum dubium was 1.375 and was considered as Not Threatened (NT). Cinnamomum ovalifolium was distributed only in Nuwara Eliya, Kandy and Badulla districts. ARLSV of this species was 2.25 and national red list status was considered as Indeterminate (I). Cinnamomum litseaefolium was limited to Kandy and Matale districts with ARLSV of 3.125 and nationally red listed as Threatened (T). Cinnamomum rivulorum was limited only to Sinharaja forest reserve and was a very rare species. ARLSV of this species was 3.5 and nationally red listed as Threatened. Cinnamomum sinharajaense was distributed in Sinharaja forest reserve and it was a rare species with 3.625 ARLSV and was considered as Threatened. Cinnamomum capparucoronde was limited to the low country wet zone rain forests and was also considered as a rare species. ARLSV of this species was 4 and considered as Highly Threatened (HT). Cinnamomum citriodorum was limited from Balangoda to the Haputale region with scattered distribution and ARLSV of this species was 4.5. Therefore, this species was also considered as Highly Threatened. Lack of awareness, habitat destruction, urbanization and unsuitable agriculture practices were the major threats to wild cinnamon.
\end{abstract}

\footnotetext{
1 Department of Agricultural Biology, Faculty of Agriculture, University of Ruhuna, Sri Lanka

2 Horticultural Research and Development Institute, Gannoruwa, Peradeniya, Sri Lanka

3 Department of Royal Botanical Garden, Peradeniya, Sri Lanka

4 Mid Country Research Station, Department of Export Agriculture, Dalpitiya, Atabage, Sri Lanka
} 


\section{INTRODUCTION}

Close relatives of cultivated plants are called Crop Wild Relatives (CWR). N.I. Vavilov a Russian Botanist first realized the importance of crop wild relatives in the early years of the $20^{\text {th }}$ century (Vavilov, 1926). In addition, crop wild relatives are essential components of natural ecosystems and agricultural ecosystems. Hence, they are indispensable for maintaining healthy ecosystems (Wijesundara, 2006). Thus, conservation and sustainable uses of them are very important for improving cultivated crops, increasing food security and maintaining ecosystem health.

In Sri Lanka, cinnamon seems to have originated in the central hills where several species of cinnamon occur sporadically in places such as Kandy, Matale, Belihul Oya, Haputale and the Sinharaja forest range (Wijesinghe and Pathirana, 2000). Although cinnamon (Cinnamomum verum) cultivation is presently concentrated along the coastal belt stretching from Negombo to Matara, it has also made inroads to the inlands of Kalutara, Ambalangoda, Matara and Ratnapura. The importance of cinnamon in the economy of Sri Lanka since European colonization to post independence era is well documented by Pethiyagoda (2007).

According to the records of the National Herbarium of Sri Lanka, 661 species of crop wild relatives have been identified. Out of these, 122 species are endemic and 159 species are naturalized exotic species. One of the most important genera containing crop wild relatives is the genus Cinnamomum. Nine species belonging to the genus Cinnamomum were recorded in Sri Lanka (Sritharan, 1984). Among these species seven are endemic. This study was mainly focused on the endemic wild cinnamon species. According to the National Red List of Sri Lanka, published in 2000, Cinnamomum capparu-coronde and Cinnamomum litseaefolium were threatened and Cinnamomum citriodorum was highly threatened (IUCN Sri Lanka, 2000). Other species have not been analyzed by IUCN due to lack of information and primary data have not been used for the 2000 IUCN national red listing analysis. Another weakness of the IUCN study in 2000 was some of the assesment methods used do not fit the Sri Lankan conditions. For example, the method used to calculate the Area of Occupancy (AOO) is not relevant to a small country like Sri Lanka. Therefore, National Red Listing assessing criteria used by IUCN in 2000 need to be modified to fit the conditions in Sri Lanka.

Wild cinnamon species are secondary gene pools of cultivated cinnamon. Therefore conservation of the secondary gene pool is important. Apart from that, most of these wild cinnamon species have been used for medicinal purposes and therefore there is a high ethnobotanical value. However, the information about the current status of endemic wild cinnamon in Sri Lanka is limited. Therefore, all endemic wild cinnamon species were analyzed using primary data collected by a field exploration and from reliable secondary data to determine the national red list status of the endemic wild cinnamon species and to assess their extinction risk.

\section{MATERIALS AND METHODS}

This study was mainly based on an eco-geographical survey which consisted of the study of the herbarium specimens to collect reliable secondary data and development of potential distribution maps using available data. DIVA-GIS software was used to develop potential maps. The high potential areas were identified using the above maps and field visits were 
made to collect primary data. Collected primary data were analyzed and national red listing criteria were applied (Guarino, 2005).

During the collection of secondary data for potential map preparation, all Cinnamomum specimens available at the National Herbarium were observed and locations, date of collection, name of the collector, morphology and habitat information were recorded. Collected secondary data were transformed into GPS data and were plotted on the map of Sri Lanka by using DIVA-GIS 5.4 software and potential distribution maps for each species were developed (Fig. 1).

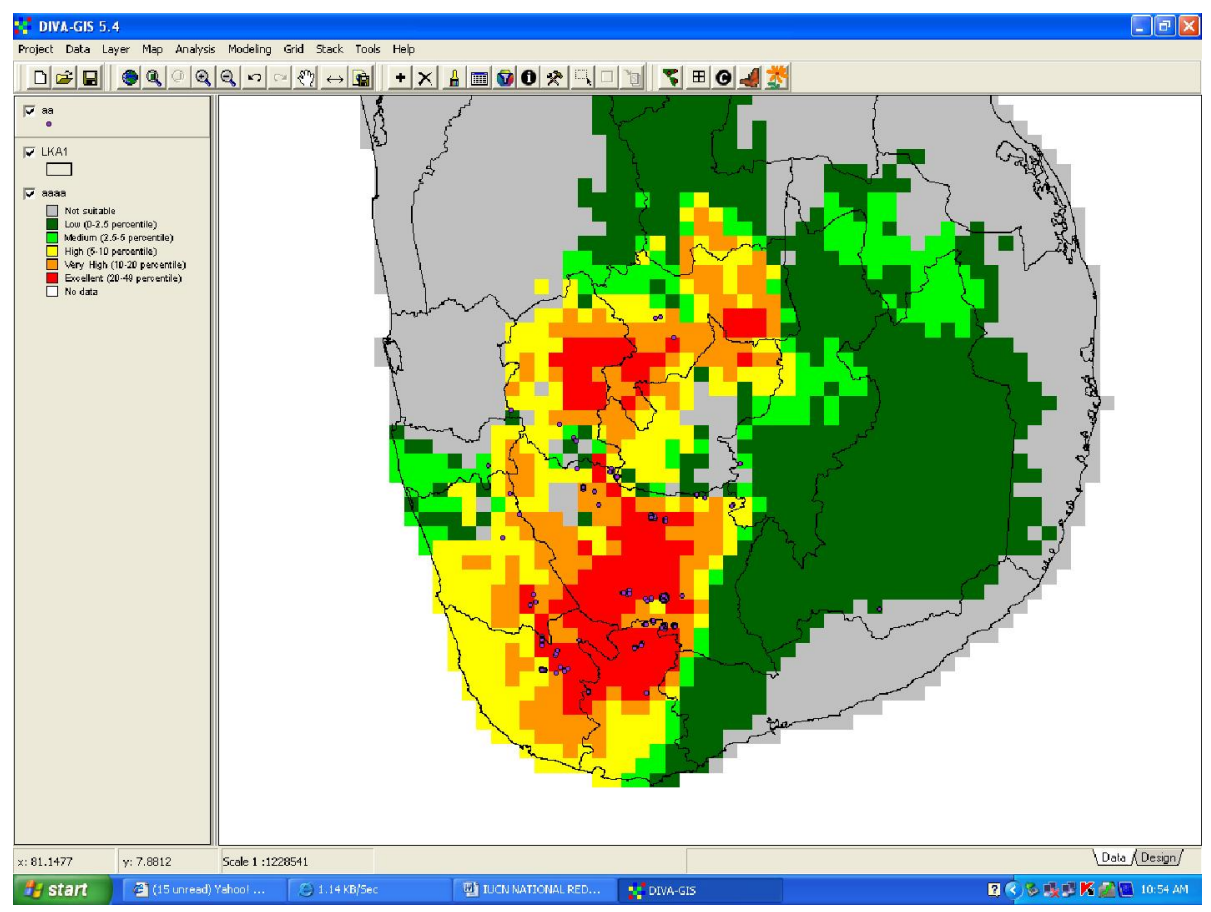

\section{Fig. 1. Potential distribution map}

The prepared potential maps were carefully studied and high potential areas were identified. Field visits were made to the high potential areas and also to the previously recorded locations. During the field visits, visual encounter survey (VES) was carried out. Population data were not collected due to wild cinnamon species being distributed in large areas of the Island and therefore not practically feasible. For the collection of primary data during the field visits, line transects were used to monitor and collect the samples in every forest patch visited.

During each field visit, collection date, GPS readings, morphological characters of plant, ecological condition of surrounding area, altitude, slope, aspect, ethno-botanical uses and main causes of threat were recorded. Furthermore, 2-3 twigs from a representative plant of each location were also collected to prepare herbarium specimens. Ethno-botanical uses and causes of threats were recorded from an interview of villagers/users. 
Data were analyzed using IUCN 2000 national red listing criteria (Table 1). For more reliable results, the Area of Occupancy (AOO) was calculated using $2 \times 2 \mathrm{~km}^{2}$ grid map (IUCN, 2008). All the red list criteria values used and relevant red list group are given in Table 2.

Extinction risks were assessed from field observations and Anthropological data. Constant scoring scale was used for assessing the severity of threats. Threats identified for each location, were given a severity scale value and finally a total value was calculated. Threats with the highest severity values were identified as major threats of wild cinnamon. In addition, highly threatened locations were identified from field observations.

Table 1. Criteria and Scoring System

\begin{tabular}{|c|c|c|c|c|c|c|}
\hline CRITERIA & Score of 5 & Score of 4 & Score of 3 & Score of 2 & Score of 1 & Score of 0 \\
\hline $\begin{array}{l}\text { Extent of } \\
\text { geographical } \\
\text { range and } \\
\text { rarity }\end{array}$ & $\begin{array}{l}\text { Very rare; } \\
\text { found in one } \\
\text { zone }\end{array}$ & $\begin{array}{l}\text { Very rare; } \\
\text { found in } \\
\text { more than } \\
\text { one zone }\end{array}$ & $\begin{array}{l}\text { Rare; found } \\
\text { in one zone }\end{array}$ & $\begin{array}{l}\text { Rare; found } \\
\text { in more than } \\
\text { one zone }\end{array}$ & $\begin{array}{l}\text { Common, } \\
\text { but found } \\
\text { in one } \\
\text { zone }\end{array}$ & $\begin{array}{l}\text { Common } \\
\text { and found in } \\
\text { more than } \\
\text { one zone }\end{array}$ \\
\hline $\begin{array}{l}\text { Area of } \\
\text { Occupancy } \\
\left(\mathbf{k m}^{2}\right)\end{array}$ & $\leq 8$ & $09-20$ & $21-40$ & $41-120$ & $121-200$ & $>200$ \\
\hline $\begin{array}{l}\text { Restricted } \\
\text { populations }\end{array}$ & $\begin{array}{l}\text { Very } \\
\text { restricted }\end{array}$ & - & - & - & - & - \\
\hline $\begin{array}{l}\text { Habitat status } \\
\text { (per cent of } \\
\text { habitat under } \\
\text { protection) }\end{array}$ & $0-25 \%$ & $26-40 \%$ & $41-55 \%$ & $56-65 \%$ & $66-75 \%$ & $>75 \%$ \\
\hline $\begin{array}{l}\text { Intrinsic } \\
\text { characters }\end{array}$ & $\geq 10+$ & $9+$ to $8+$ & $7+$ to $6+$ & $5+$ to $4+$ & $3+$ & $\leq 2$ \\
\hline $\begin{array}{l}\text { Human impact } \\
\text { on the habitat }\end{array}$ & $\geq 8+$ & $7+$ to $6+$ & $5+$ to $4+$ & $3+$ to $2+$ & $1+$ & $\begin{array}{l}\text { Recorded } \\
\text { as no impact }\end{array}$ \\
\hline $\begin{array}{l}\text { Recorded } \\
\text { human impact } \\
\text { on the species }\end{array}$ & 10 points & 9 points & $\begin{array}{l}8 \text { to } 7 \\
\text { points }\end{array}$ & $\begin{array}{l}6 \text { to } 5 \\
\text { points }\end{array}$ & $\begin{array}{l}4 \text { to } 3 \\
\text { points }\end{array}$ & 2 points \\
\hline $\begin{array}{l}\text { Endemism/ } \\
\text { global threat } \\
\text { status }\end{array}$ & Endemic & & $\begin{array}{l}\text { Globally } \\
\text { threatened }\end{array}$ & & & Others \\
\hline
\end{tabular}

Table 2. Cut off point of national red listing criteria average values

\begin{tabular}{lllll}
\hline Category & $\begin{array}{l}\text { Highly } \\
\text { Threatened }\end{array}$ & Threatened & Indeterminate & Not Threatened \\
\hline Average Score & $\geq 4$ & $3.9-3$ & $2.9-2$ & $1.9-0$ \\
Abbreviation & HT & T & I & NT \\
\hline
\end{tabular}




\section{RESULTS AND DISCUSSION}

Wild cinnamon species were recorded in twelve districts of Sri Lanka. Among these districts wild cinnamon species are commonly found in Ratnapura, Galle, Matara, NuweraEliya, Badulla and Kandy districts (Fig. 2). Endemic wild Cinnamomum species were mainly concentrated in and around Sinharaja forest reserve, Enasalwatte-Deniyaya, Kanneliya forest reserve, Walankanda forest reserve, Horton Plains N.P., Gilimale-Erathne proposed reserve, Peak-Wilderness sanctuary, Knuckles conservation area and Haldummulla - Halpe regions. Considerable variations in morphology were observed among these locations. This may probably be due to the diversity in climate among these locations.

Cinnamomum dubium has a good survival rate in different areas and it is a common species (Table 3 and Fig. 3). Cinnamomum ovalifolium was mainly limited to the up country forest area. Therefore, it is a common species in higher elevations of Sri Lanka (Table 3 and Fig. 4). Cinnamomum capparu coronde has a scattered distribution in low country rain forests and it could be considered as a rare species (Table 3 and Fig. 5). Cinnamomum litseaefolium was recorded only in Knuckles conservation areas where it is commonly available (Table 3 and Fig. 6). Cinnamomum sinharajaense and Cinnamomum rivulorum seemed to be very rare species and recorded only in Sinharaja forest reserve (Table 3 and Fig. 7 and 8). Cinnamomum citriodorum is only recorded in Balangoda to Haputale regions showing a scattered distribution (Table 3 and Fig. 9).

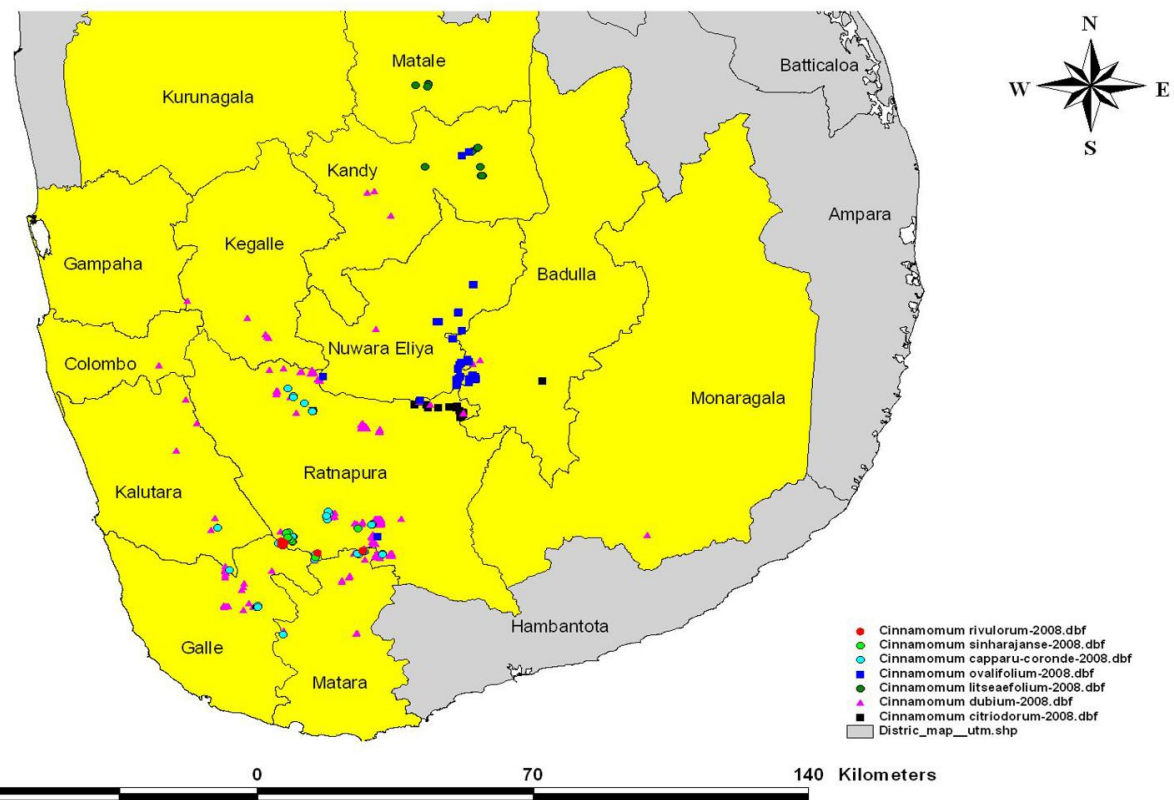

Fig. 2. Wild cinnamon distribution map 


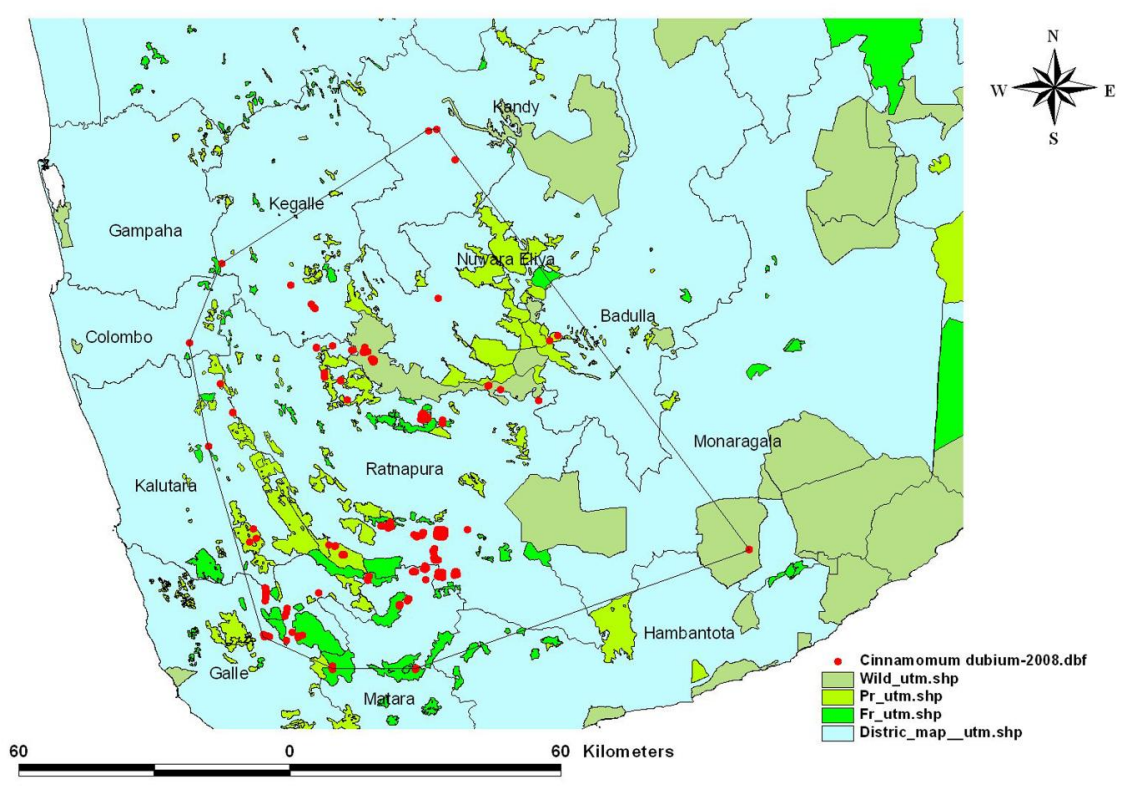

Fig. 3. Cinnamomum dubium distribution map with protected areas

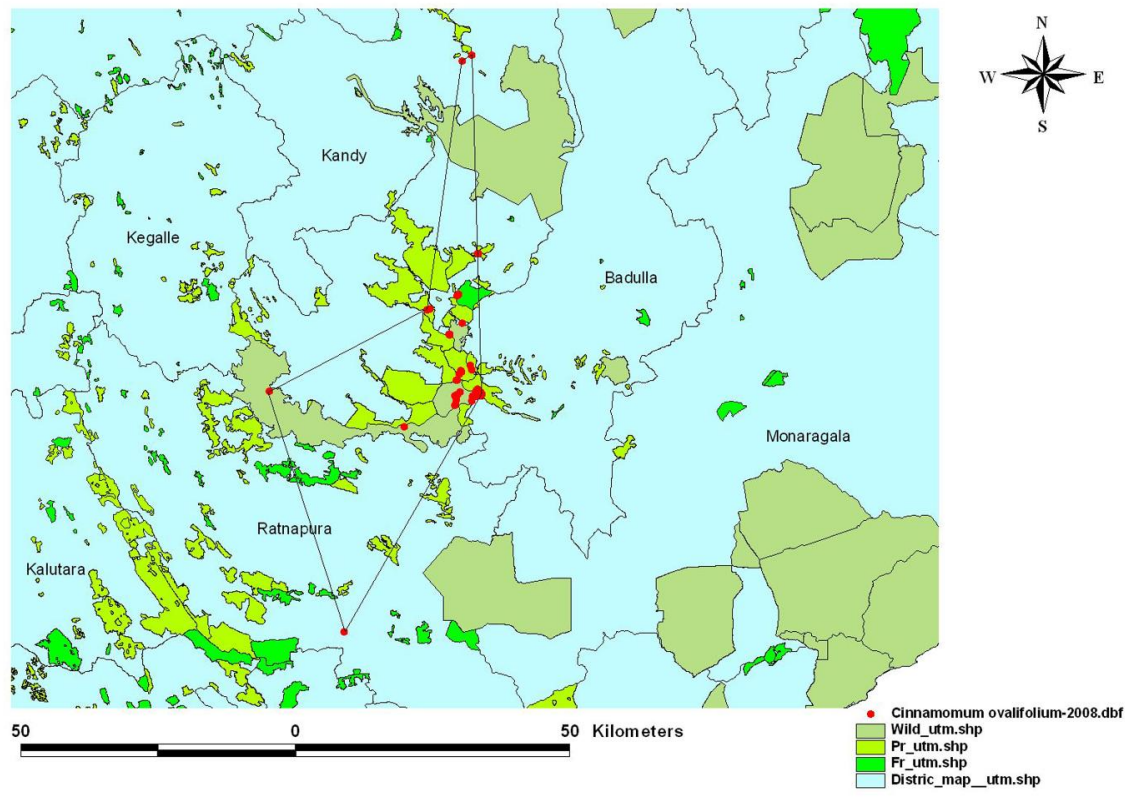

Fig. 4. Cinnamomum ovalifolium distribution map with protected areas 


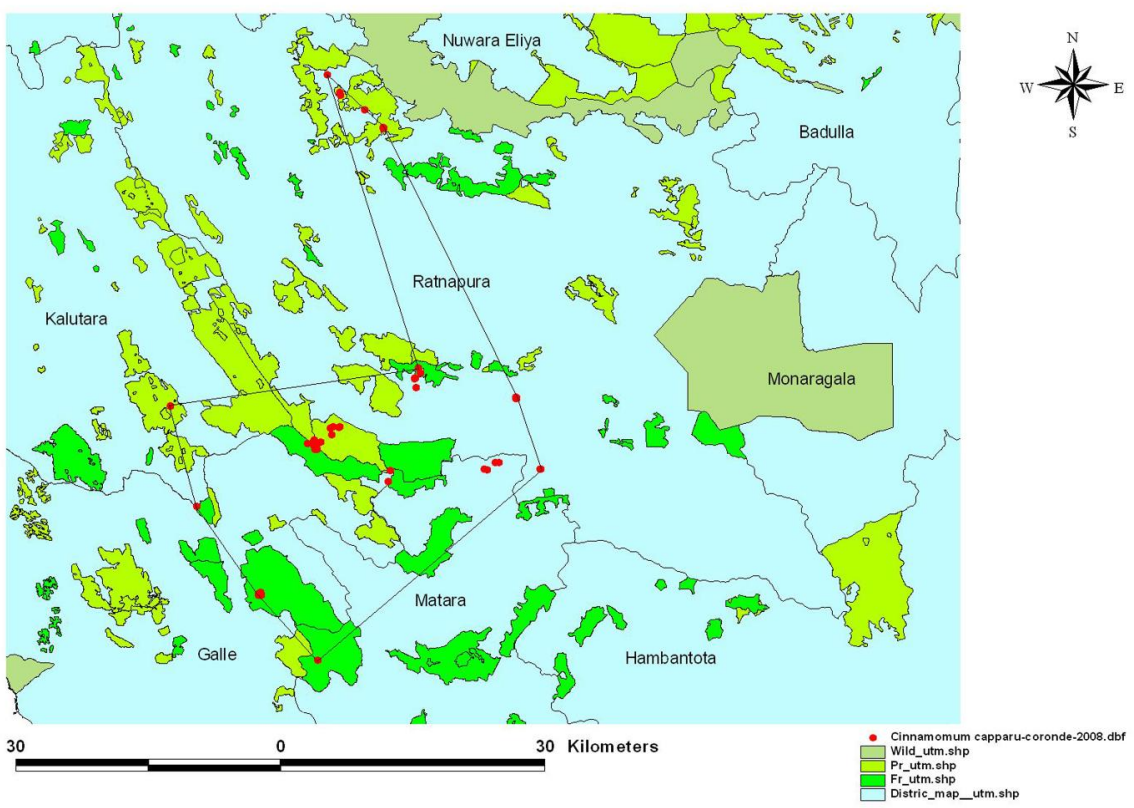

Fig. 5. Cinnamomum capparu coronde distribution map with protected areas

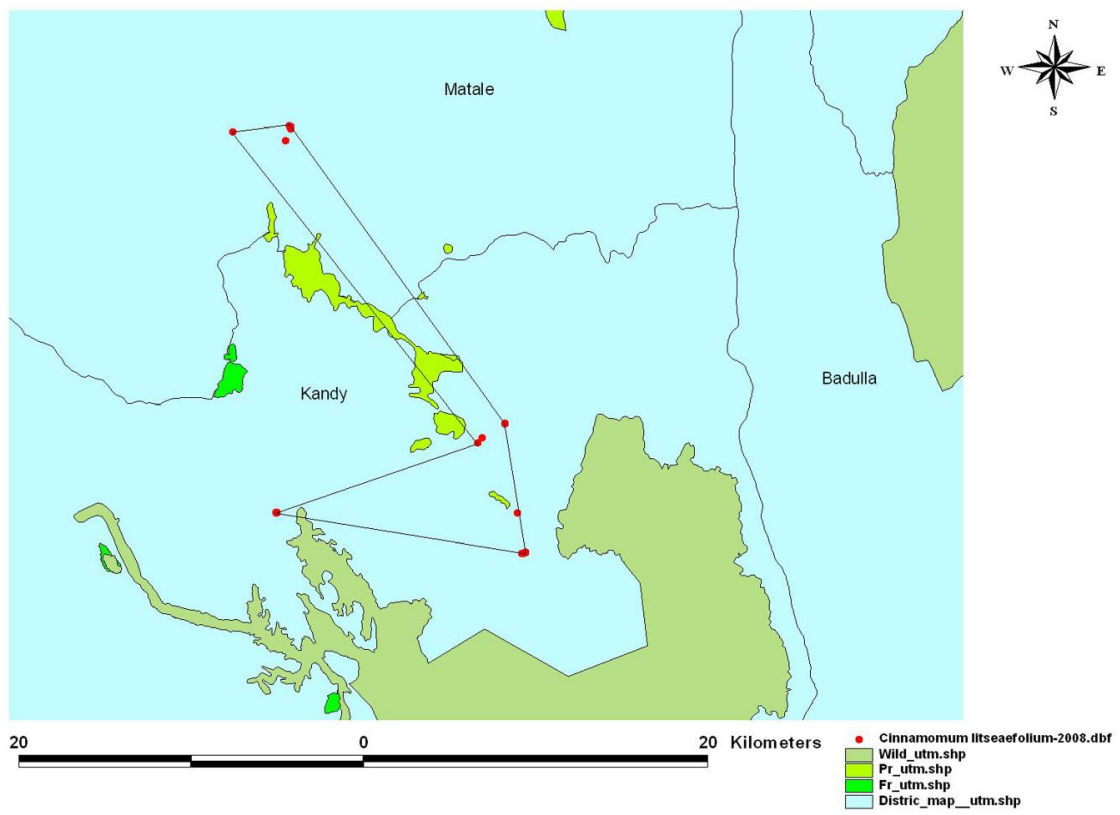

Fig. 6. Cinnamomum litseaefolium distribution map with protected areas 
Kumarathilake et al.

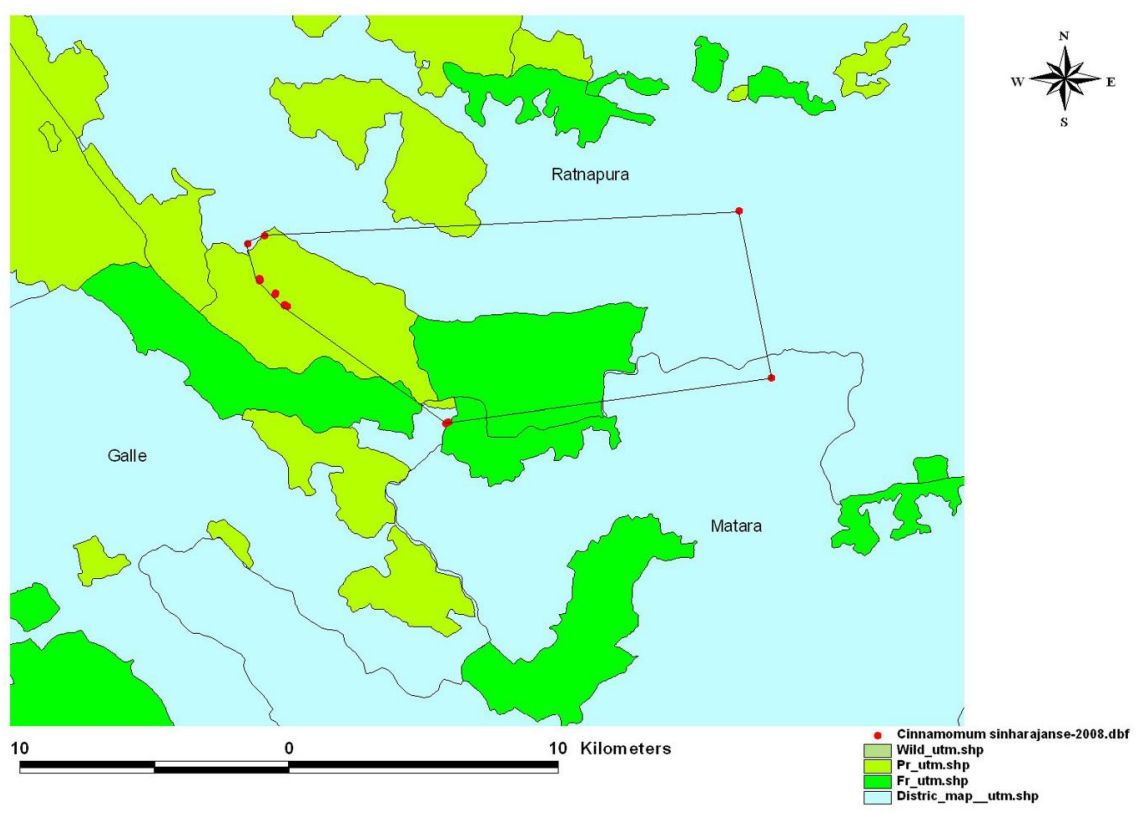

Fig. 7. Cinnamomum sinharajaense distribution map with protected areas

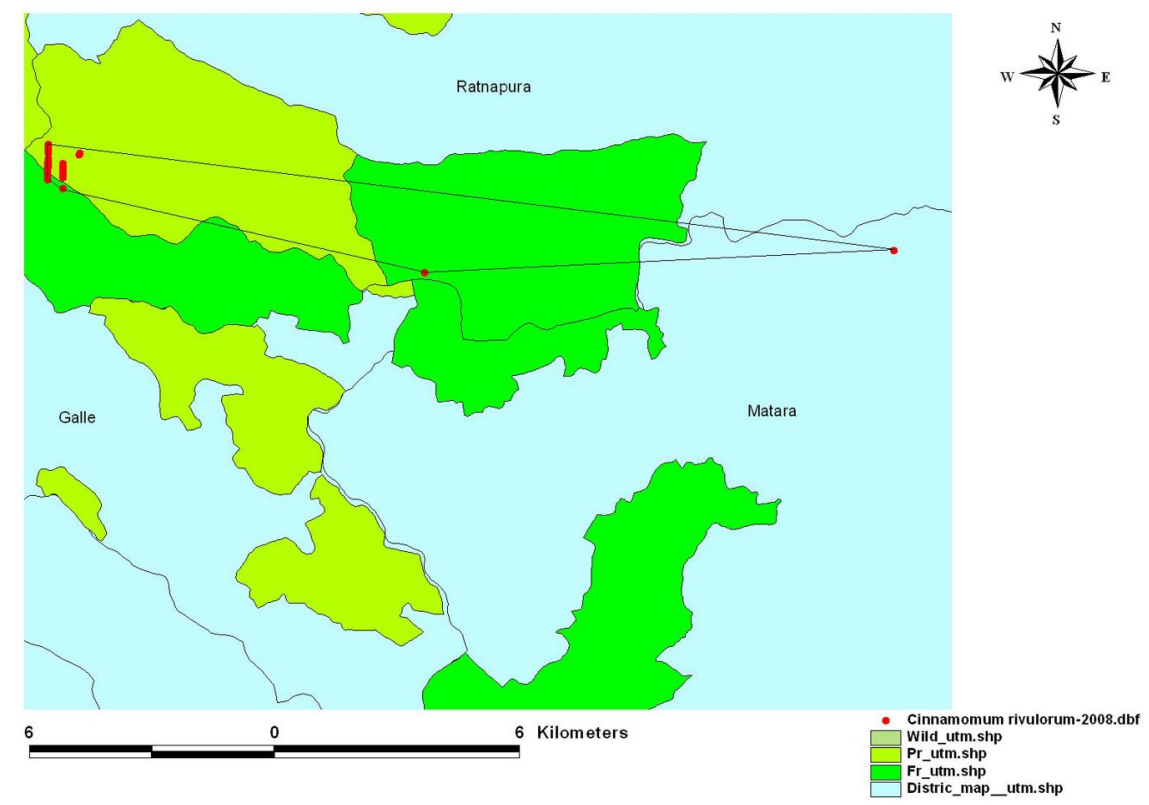

Fig. 8. Cinnamomum rivulorum distribution map with protected areas 


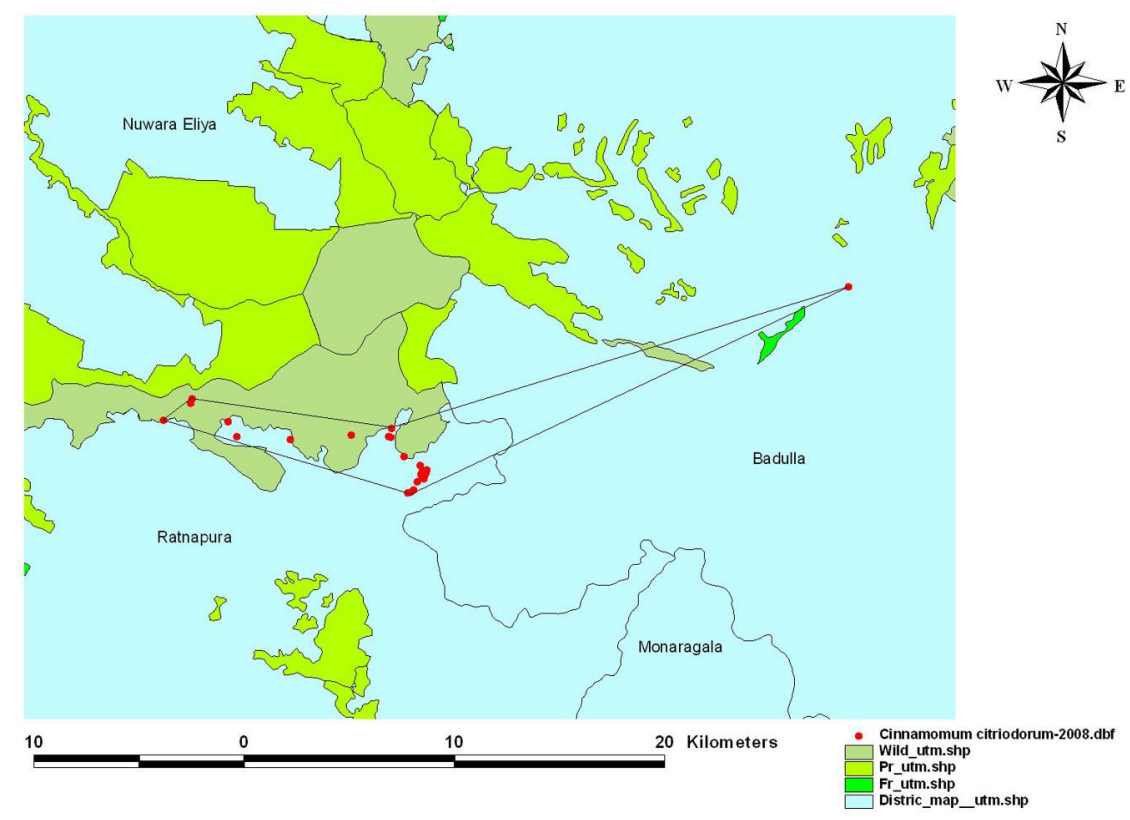

Fig. 9. Cinnamomum citriodorum distribution map with protected areas

Table 3. Distribution of endemic wild cinnamon species

\section{Species name}

\begin{tabular}{ll}
\hline Cinnamomum dubium & Galle, Matara, Kalutara, Rathnapura, Kegalle, \\
& Colombo, Gampaha, Badulla and Kandy districts \\
Cinnamomum ovalifolium & Kandaploa-Sita Eliya PR, Hakgala S.N.R., Horton \\
& N.P., Peak Wilderness Sanctuary, Kikiliyamana PR \\
& and Mahakudugala PR \\
Cinnamomum capparu-coronde & Sinharaja FR, KDN complex, Gilimale-Erathne \\
& PR, Gongala PR, Enasalwatte PR, Walankanda FR, \\
& Kalugala PR and Haycocks FR \\
Cinnamomum litseaefolium & Knuckles Conservation Area \\
Cinnamomum sinharajaense & Sinharaja FR \\
Cinnamomum rivulorum & Sinharaja FR \\
Cinnamomum citriodorum & Halpe, Norwood and Haputale region \\
\hline
\end{tabular}

Red listing analysis values were calculated according to the national red listing criteria given in Table 4. Cinnamomum dubium and Cinnamomum ovalifoium showed minimum analysed values. Therefore, these two species have very low threatened level. Cinnamomum litseaefolium, Cinnamomum rivulorum and Cinnamomum sinharajaense show medium values and therefore these species have reached the threatened level. Cinnamomum capparu coronde and Cinnamomum citriodorum have shown highest values and therefore these two species are in the highly threatened and unprotected category. 
Table 4. Average red listing criteria value

\begin{tabular}{lcl}
\hline Species name & Average scoring value & \multicolumn{1}{c}{ Red list category } \\
\hline Cinnamomum dubium & 1.375 & Not Threatened (NT) \\
Cinnamomum ovalifolium & 2.250 & Indeterminate (I) \\
Cinnamomum litseaefolium & 3.125 & Threatened (T) \\
Cinnamomum rivulorum & 3.500 & Threatened (T) \\
Cinnamomum sinharajaense & 3.625 & Threatened (T) \\
Cinnamomum capparu-coronde & 4.000 & Highly Threatened (HT) \\
Cinnamomum citriodorum & 4.500 & Highly Threatened (HT) \\
\hline
\end{tabular}

According to the field observation and Anthropological data, lack of awareness, habitat destruction, urbanization and poor agricultural practices were found to be the major threats to the wild cinnamon species. In addition, the following forest patches (habitat locations) were identified as currently unprotected due to above reasons.

1. Sinharaja division - Enasalwatte (Matara district)

2. Ihalakurulugala - Enasalwatte (Matara district)

3. Wavul lena kanda - near Haycock forest reserve (Galle district)

4. Idigastanne - Halpe (Ratnapura district)

5. Tumbatanne - Halpe (Ratnapura district)

6. Donawa Mukalana - Ratganga (Ratnapura district)

7. Great western forest - Radalla (Nuwera Eliya district)

8. Namunukula proposed reserved - (Badulla district)

9. Gilimale Errante proposed reserve - (Ratnapura district)

10. Knuckles conservation areas - Hunnasgiriya - (Kandy district)

11. Walankanda forest reserve - (Ratnapura district)

12. Hadapan Ella proposed reserve (Ratnapura district)

\section{CONCLUSIONS}

Cinnamomum dubium is a common species in mature tropical rain forests and in secondary forests, that falls into the Not Threatened (NT) category. It shows a good survival rate under different climatic conditions. Cinnamomum ovalifolium falls into the Indeterminate (I) category and considered as a common species in Montane forests in high elevations. Cinnamomum litseaefolium is a Threatened (T), rare species and only found in the Knuckles conservation area. Both Cinnamomum rivulorum and Cinnamomum sinharajaense are Threatened ( $\mathrm{T}$ ) very rare species and only found in the Sinharaja forest reserve. Cinnamomum capparu-coronde is a Highly Threatened (HT) rare species, showing scattered distribution and only found in the low country rain forest. Cinnamomum citriodorum is a Highly Threatened (HT), rare species and only found in the Belihul oya - Halpe - Haputale region. These species were threatened mainly due to lack of awareness, habitat destruction, urbanization and unsuitable agriculture practices.

Cinnamomum citriodorum and Cinnamomum capparu coronde should be conserved immediately. In addition, Cinnamomum rivulorum, Cinnamomum sinharanjaense and Cinnamomum litseaefolium are threatened and in the near future these will come into the highly threatened category. Therefore, conservation practices of these species are also needed. 


\section{ACKNOWEDGEMENT}

This publication presents part of the findings of the international project "In situ conservation of Crop Wild Relatives Through Enhanced Information Management and Field Application" implemented in five countries-Armenia, Bolivia, Madagascar, Sri Lanka and Uzbekistan. The project is coordinated by the Biodiversity International with co-financing from the Global Environmental Facility (GEF), and implementation support from the United Nations Environment Program (UNEP).

\section{REFERENCES}

Guarino, L., Maxted, N. and Chiwona, E.A. (2005). A methodological model for ecogeographic surveys of crops, IPGRI, Rome, Italy.

IUCN (2008). Guidelines for using the IUCN Red List Categories and Criteria: Version 7. Prepared by the Standards and Petitions Working Group IUCN, Gland, Switzerland and Cambridge, U.K.

IUCN Sri Lanka, (2000). The 1999 list of threatened fauna and flora of Sri Lanka, Colombo, Sri Lanka.

Pethiyagoda, R. (2007). Pearls, spices and green gold. An illustrated history of biodiversity exploration in Sri Lanka. Wildlife Heritage Trust Publications

Sritharan, R. (1984). The study of genus Cinnamon, M.Phil. thesis, PGIA, Peradeniya, Sri Lanka.

Vavilov, N.I., (1926). Studies in the origin of cultivated plants. Institute of Applied Botany and Plant Breeding, Leningrad.

Wijesinghe, K.G.G. and Pathirana, R. (2000). Germplasm screening and varietal development of cinnamon (Cinnamomum verum Presl.) pp. 15 - 17. In: Senarathne, R. and Dayathilake, D.A. (Eds). Revitalization of Cinnamon Industry in Sri Lanka, Premadasa Printers, Matara, Sri Lanka.

Wijesundara, S. (2006). Spicy wild relatives get some respect pp. 26 - 28. In: Raymond, R.D. and Moore, C. (Eds). Geneflow, Bioversity International, Malaysia. 